\title{
Variación del módulo de Young de un elemento de fábrica de ladrillo sometido a altas temperaturas
}

\section{Young modulus variation of a brickwork masonry element submitted to high temperatures}

\author{
M. E. Maciá(*); A. Rolando(**)
}

Recepción/Received: 28-IV-11

Aceptación/Accepted: 29-XI-11

Publicado online/Online publishing: 29-II-12

\section{RESUMEN}

La definición del comportamiento térmico de los elementos de fábrica sometidos a la acción del fuego requiere del conocimiento de la variación de sus propiedades termomecánicas con respecto a la temperatura. Ante las altas temperaturas la fábrica cerámica presenta efectos termomecánicos, como la variación del módulo de Young entre otros, así como la variación de las propiedades del material debidas a la degradación del mismo. En este artículo se describe la variación del módulo de elasticidad de la pieza y el mortero con respecto a altas temperaturas según el estado del conocimiento y se exponen los resultados obtenidos del programa experimental llevado a cabo sobre elementos de fábrica sometidos a altas temperaturas con el fin de observar la variación del módulo de Young con respecto a la temperatura.

Palabras clave: fábrica de ladrillo; altas temperaturas; módulo de Young; comportamiento termomecánico.

\section{SUMMARY}

In order to understand the thermal behavior of the masonry elements submitted to high temperatures we need to know the variation of their thermal properties with regard to the temperature. Submitted to high temperatures clay brick masonry presents thermomechanical effects (as the variation of Young's modulus, the thermal expansion of the unit and the mortar, spalling, losses of resistance...) as well as variation of the properties of the material as result of its degradation. In this article the variation of the module of elasticity of the unit and the mortar is described with regard to high temperatures according to the state of the knowledge. In this article is also exposed the results obtained from the experimental program carried out on elements of clay brick masonry submitted to high temperatures in order to observe the variation of Young's module related to temperature.

Keywords: brickwork masonry; high temperatures; Young 's modulus; thermo mechanical behaviour.
(*) Universidad San Pablo CEU. (Madrid, España).

(**) Universidad Politécnica de Madrid (Madrid, España). 


\section{INTRODUCCIÓN}

La fábrica es un material compuesto, heterogéneo, constituido por dos materiales de características distintas: las piezas (ya sean ladrillos cerámicos, bloques de hormigón u otros) y las juntas de mortero. Su comportamiento termomecánico es muy complejo, función de las características termomecánicas de las unidades y del mortero que la componen. Además, las condiciones de construcción y mano de obra tienen un gran efecto en el comportamiento general de la fábrica.

\section{ESTADO DEL CONOCIMIENTO}

Por su definición, el módulo de Young es constante en todo el régimen elástico del material. Sin embargo, en tanto en cuanto la elasticidad del material varía drásticamente con la temperatura, es de esperar que el Módulo de Young refleje esta variación E (T). A continuación se enuncian brevemente algunos de resultados que, sobre la variación de este parámetro, existen en la literatura.

\subsection{Sobre la pieza}

Los Módulos de Elasticidad de los elementos cerámicos a temperatura ambiente fueron definidos por Page hacia 1978. Algunos ensayos realizados sobre piezas cerámicas sometidas a altas temperaturas señalan que los ladrillos no tienen una pérdida significativa de resistencia con la temperatura. Basado en estos datos y en ausencia de más referencias, se puede concluir que la temperatura no tiene ningún efecto significativo en el módulo de elasticidad de los ladrillos cerámicos (E ladrillos=3.000-5.000 N/mm²).

Diversos estudios (1) han comprobado que la pérdida de resistencia a compresión de una pieza cerámica a temperatura ambiente y a altas temperaturas se mantiene constante cuando las temperaturas alcanzadas no superan los $700^{\circ} \mathrm{C}$.

Dado que el módulo de elasticidad de los materiales cerámicos está íntimamente relacionado con el aspecto tenso-deformacional del material y unido al comportamiento frágil del mismo podemos inferir que el módulo de elasticidad del material es similar tanto a altas temperaturas como a temperatura ambiente.

\subsection{Sobre el mortero}

El mortero utilizado en la ejecución de muros de fábrica está compuesto por diferentes combinaciones de cemento, arena y finos. La resistencia alcanzada por el mortero suele ser menor que la del ladrillo. El mortero presenta un comportamiento no-lineal a nivel tenso-deformacional

\section{INTRODUCTION}

The masonry is a composite heterogeneous element consisting of two materials with different characteristics: the pieces (clay bricks, concrete blocks or other) and the mortar joints. In addition, conditions of construction and labour have a great effect on the overall performance of the masonry.

\section{STATE OF KNOWLEDGE}

By definition, the Young's modulus is constant throughout the elastic regime of the material. However, as long as the elasticity of the material varies dramatically with temperature, it is expected that the Young's modulus reflects this variation $E(T)$. Then some results on the variation of this parameter existing in the literature are set out briefly.

\subsection{About the piece}

Modulus of elasticity of the ceramic elements at ambient temperature were defined by Page around 1978. Some tests performed on ceramic pieces submitted to high temperatures indicate that the bricks do not have a significant loss of resistance with temperature. Based on these data and in the absence of further reference, we can conclude that temperature has no significant effect on the modulus of elasticity of clay bricks (3000 N) $\mathrm{mm}^{2}<$ Ebrick $<5000 \mathrm{~N} / \mathrm{mm}^{2}$ ).

Several studies (1) have shown that the loss of compressive strength of a ceramic piece at ambient temperature and at high temperature remains constant when the temperatures do not exceed $700{ }^{\circ} \mathrm{C}$.

Since the modulus of elasticity of ceramic material is closely related to the stress-strain aspect of the material and considering the brittle behaviour of it we can infer that the modulus of elasticity of the material is similar at both high temperatures and at ambient temperature.

\subsection{About the mortar}

The mortar used in the construction of masonry walls is composed of different combinations of cement, sand and fines. The compression strength attained by the mortar is usually less than the brick. The strength attained by the mortar is usually less than the brick. The mortar has 
que provoca deformaciones inelásticas significativas en el muro de fábrica (2).

Algunos estudios (3) proporcionan gráficos sobre la variación del módulo de elasticidad del hormigón que puede asimilarse al del mortero. El porcentaje de reducción del Módulo de elasticidad, con respecto a la temperatura, del mortero se puede tomar como el del hormigón (4).

En los primeros resultados de los que se dispone (3) el porcentaje remanente del módulo de elasticidad del mortero en función de la temperatura llega al 50\% a los $400{ }^{\circ} \mathrm{C}$ y hacia los $800{ }^{\circ} \mathrm{C}$ el porcentaje remanente del módulo de elasticidad llega al 20\%.

En la Figura 1 se presenta el porcentaje de pérdida del Módulo de elasticidad del mortero común en función de la temperatura según diversos autores (4-9). a nonlinear behaviour at the stress-strain level causing significant inelastic deformations in the masonry wall (2).

Some studies (3) provide graphs of the variation of the modulus of elasticity of concrete that can be assimilated to the mortar. The percentage reduction in the modulus of elasticity with respect to temperature of the mortar can be taken as the concrete (4).

In the first results of which are available (3) the loss of stiffness of the mortar as a function of the temperature reaches $50 \%$ at $400{ }^{\circ} \mathrm{C}$ and at $800{ }^{\circ} \mathrm{C}$ the decrease of the elastic modulus reaches $20 \%$ of the initial one.

Figure 1 shows the percentage of loss of modulus of elasticity of common mortar in function of temperature according to different authors (4-9).

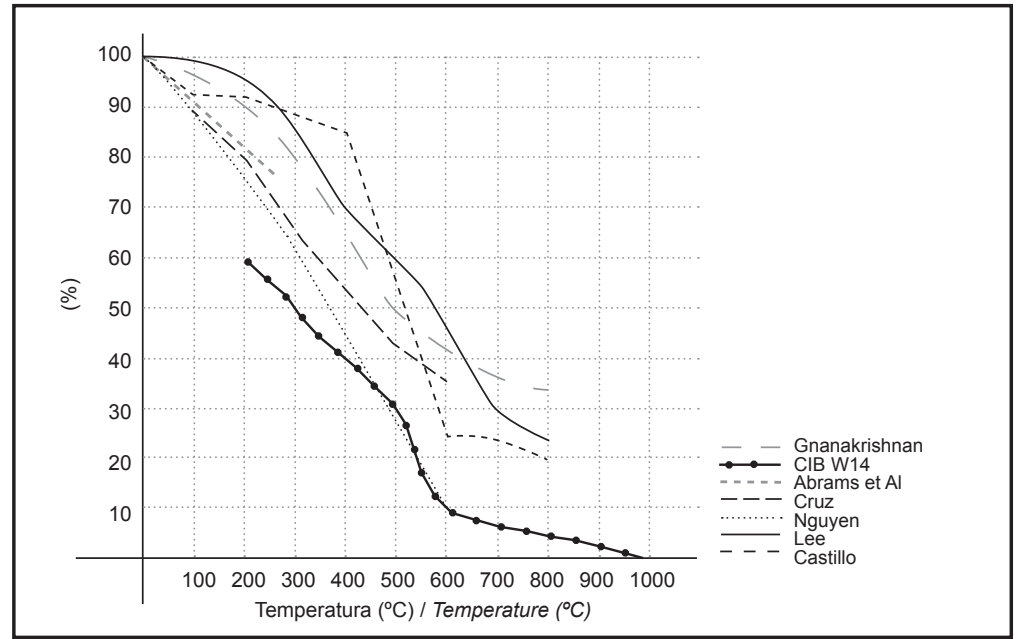

Figura 1. Variación del Módulo de Elasticidad del mortero en función de la temperatura.

Figure 1. Variation of the modulus of elasticity of the mortar as a function of temperatura.

En todos ellos se aprecia una brusca disminución del módulo de elasticidad entre las temperaturas de $200{ }^{\circ} \mathrm{C}$ a $600{ }^{\circ} \mathrm{C}$ (la disminución oscila entre el $20 \%$ y el $70 \%$, respectivamente).

A temperatura ambiente el mortero presenta un comportamiento a tracción elasto-frágil y un poco elástico a compresión. A altas temperaturas el Módulo de Young disminuye de forma casi lineal mientras la temperatura aumenta. Mientras sucede esto el comportamiento del material gana en ductilidad. La disminución del Módulo de Elasticidad del mortero alcanza el $90 \%$ a los $600{ }^{\circ} \mathrm{C}$ y a $900{ }^{\circ} \mathrm{C}$ la disminución es del 100\% (8).

Existen estudios (10) en los que se han determinado las resistencias mecánicas del mortero M7,5 (Tabla 1) sometido a altas temperaturas.
In all cases e see a sharp drop in elastic modulus between the temperatures of $200{ }^{\circ} \mathrm{C}$ to $600{ }^{\circ} \mathrm{C}$ (reduction between $20 \%$ and $70 \%$, respectively).

At ambient temperature mortar presents a quasi-brittle tension behaviour and a little ductile compression behaviour. At high temperatures the material strength (both tensile and compression) and Young's modulus decrease almost linearly as the temperature increases. While this happens the behaviour of the material gain in ductility. The reduction in modulus of elasticity of the mortar reaches $90 \%$ at $600^{\circ} \mathrm{C}$ and at $900^{\circ} \mathrm{C}$ the loss is $100 \%$ (8).

There are studies (10) that have determined the mechanical strength of the mortar M7, 5 (Table 1) subjected to high temperatures. 
Tabla 1 / Table 1

Datos técnicos del mortero $M 7,5$.

Technical data of the mortar M7.5.

\begin{tabular}{|c|c|}
\hline Características / Characteristics & Valor / Value \\
\hline Composición / Composition & $\begin{array}{c}\text { Conglomerantes hidráulicos, áridos seleccionados y aditivos orgánicos / } \\
\text { Hydraulic conglomerants, selected aggregates and organic additives }\end{array}$ \\
\hline $\begin{array}{c}\text { Granulometría Фmáx árido único (arena) / Grit Ф max single } \\
\text { aggregate (sand) }\end{array}$ & $<2.0 \mathrm{~mm}$ \\
\hline $\begin{array}{c}\text { Densidad aparente en polvo / Powder bulk density } \\
\text { Densidad aparente en pasta / Bulk density paste }\end{array}$ & $1400 \pm 50 \mathrm{~kg} / \mathrm{m}^{3}$ \\
\hline Densidad aparente endurecido / Apparent density hardened & $1950 \pm 50 \mathrm{~kg} / \mathrm{m}^{3}$ \\
\hline Agua de amasado relación a/c / Mixing water for w/c ratio & $1800 \pm 50 \mathrm{Kg} / \mathrm{m}^{3}$ \\
\hline Resistencia a compresión / Compressive strength & $13-15 \%$ (aprox. 3,5 litros de agua por saco de 25 Kg) / \\
\hline Reacción al fuego / Reaction to fire & $13-15 \%$ (approx. 3.5 liters of water per bag of 25 kg) \\
\hline Conductividad térmica / Thermal conductivity & $>7.5 \mathrm{~N} / \mathrm{mm}^{2}$ \\
\hline Consumo en seco / Consumption in dry & Euroclase A1 / Euroclass A1 \\
\hline
\end{tabular}

De este estudio se desprende que las probetas de mortero de albañilería $M 7,5$ ensayadas siguen un proceso de degradación frente a altas temperaturas similar a un mortero no predosificado, aunque cabe resaltar que a $600{ }^{\circ} \mathrm{C}$ aún conservan el $60 \%$ de sus resistencias a compresión por otro lado a partir de los $900{ }^{\circ} \mathrm{C}$ se desmoronan.

Otros estudios (9) presentan un rango de estudio de temperaturas de 100 a $800^{\circ} \mathrm{C}$. La presencia de las cargas se simuló precargando el elemento durante el periodo de calentamiento. Los resultados de los ensayos mostraron que la exposición a temperaturas entre 100 y 300 C reducía la resistencia a compresión del mortero en un 15-20\%. Para temperaturas de calentamiento de 400 a $800{ }^{\circ} \mathrm{C}$ el porcentaje de disminución de resistencia era del $30 \%$.

Los valores del Módulo de Elasticidad para morteros se determinaron por Page en el año 1978 de forma similar a los realizados para piezas. Los ensayos preliminares para morteros llevados a cabo en el NBTC indicaron pérdidas considerables de resistencia cuando este se exponía a altas temperaturas.

La rotura de los vínculos en la microestructura de la pasta del cemento, debida al incremento de temperatura, produce una reducción en el módulo de elasticidad. Al mismo tiempo, el incremento de la fluencia a corto plazo debido al aumento de temperaturas se manifiesta como un aparente decremento en el módulo de elasticidad (11).

La disminución del módulo de elasticidad con respecto a la temperatura se ha observado en la pasta del cemento para hormigones o morteros por varios autores.

Aunque la variedad de los resultados corresponde con la diversidad del material ensayado (distintas composiciones
This study shows that the tested specimens of masonry mortar M7.5 follow a process of degradation to high temperatures similar to a mortar Standard, although it should be noted that at $600{ }^{\circ} \mathrm{C}$ still retain $60 \%$ of its compressive strength, on the other hand from $900{ }^{\circ} \mathrm{C}$ crumble.

Other studies (9) present study range of temperatures from 100 to $800^{\circ} \mathrm{C}$. The presence of the loads was simulated by preloading the element during the heating period. The test results showed that exposure to temperatures between 100 and $300{ }^{\circ} \mathrm{C}$ reduced the compressive strength of mortar at 15-20\%. For heating temperatures from 400 to $800{ }^{\circ} \mathrm{C}$ the loss of resistance was $30 \%$.

The values of the elastic modulus of mortars were determined by Page in 1978 similar to the made for pieces. Preliminary tests conducted for mortar at the NBTC showed considerable loss of strength when it was exposed to high temperatures.

Rupture of the links in the microstructure of cement paste, due to increased temperature, produce a reduction in the modulus of elasticity. At the same time, the increase in short-term creep due to temperature rise is manifested as an apparent decrease in the modulus of elasticity (11).

The decrease in the modulus of elasticity with respect to temperature has been observed in the cement paste for concrete or mortar by several authors.

Although the variety of results corresponds to the diversity of the material tested (different compositions 
respecto a los áridos utilizados en la pasta, fibras empleadas..., variación en los grados de resistencia...) los resultados apuntan hacia una misma conclusión: el módulo de elasticidad del mortero sometido a altas temperaturas disminuye de forma continua en función de la temperatura.

\section{PROGRAMA EXPERIMENTAL}

Con el fin de realizar un estudio sobre la variación del Módulo de Young de un elemento de fábrica sometido a altas temperaturas se elabora un programa de ensayos que comprende la elección del formato de elemento ensayado, la ejecución de los muretes, la adaptación de un sistema de medición y control de temperatura o la geometría y disposición del ensayo, entre otros.

\subsection{Propiedades del material}

Para realizar los elementos de fábrica que se van a ensayar se han utilizado para su ejecución piezas cerámicas y mortero. Para la elaboración de los muretesprobeta se utilizaron ladrillos cerámicos métricos, cara vista, comunes (sin tratamientos de hidrofugación y cocidos a temperaturas próximas a $900{ }^{\circ} \mathrm{C}$ ), de $5 \mathrm{~cm}$ de canto. Los ladrillos utilizados cumplen la normativa establecida (12).

El mortero confeccionado era predosificado $M 7,5$ de uso convencional (13). El mortero se amasó con una amasadora convencional de obra (14). El agua se incorporó a la masa progresivamente, hasta encontrar una manejabilidad adecuada. No se utilizaron aditivos, plastificantes o aireantes. La retención de agua del mortero se consideró correcta en su ejecución; el mortero no manifestó pérdidas bruscas de agua en su colocación y su trabajabilidad fue buena.

\subsection{Preparación de las probetas}

Para elegir el tipo de probeta adecuado se han contrastado los estudios bibliográficos existentes aunque desde el principio se asumió que el tamaño del murete debía ser pequeño con el fin de evitar y mejorar ciertos condicionantes (problemas de replanteo, arqueo del muro, efecto de la esbeltez, problemas de excentricidad de carga, garantizar la planeidad y el paralelismo de las caras de la probeta...).

Las probetas se han realizado siguiendo las recomendaciones del Eurocódigo (15) relativas a la preparación, confección y curado de las probetas. compared to the aggregates used in the paste, fibbers used, varying degrees of resistance...) the results point to the same conclusion: the mortar under high temperatures continuously loses stiffness as a function of temperature.

\section{EXPERIMENTAL TESTING PROGRAM}

In order to conduct a study on the variation of Young's modulus of an masonry element subjected to high temperatures, it is carried out a testing program that includes the election of the tested element format, the construction of the walls, the adaptation of a temperature measurement and control system, and design of the geometry and arrangement of the trial, among others.

\subsection{Material properties}

In order to construct masonry elements to be tested, ceramic bricks and mortar have been used. For the preparation of the specimen were used common view faced metric bricks (without water-repellent treatments and cooked at temperatures near $900{ }^{\circ} \mathrm{C}$ ), $5 \mathrm{~cm}$ thick. The bricks used comply with the established standard (12).

The mortar made was predosed M7.5 conventional use (13). The mortar was mixed with a conventional work mixer. The water mass was progressively joined to find a proper handling. No use of additives, plasticizers, air-entraining agents. Water retention of the mortar was considered correct in its carrying-out; the mortar showed no sudden loss of water in its placement and its workability was good. Water retention of the mortar was deemed correct in their implementation, the mortar showed no sudden loss of water in its placement and its workability was good.

\subsection{Preparation of specimens}

To choose the appropriate type of specimen have been tested existing bibliographic studies but from the beginning it was assumed that the size of the wall should be small in order to prevent and improve certain conditions (staking problems, arching of the wall, the effect of the slenderness, load eccentricity problems, ensure flatness and parallelism of the faces of the specimen...).

The specimens were made following the recommendations of Eurocode (15) concerning the preparation, manufacture and curing of the specimens. 
Se han fabricado las probetas sobre una superficie lisa horizontal y se han tomado las medidas apropiadas para evitar su desecación durante los primeros días tras la construcción, tras lo cual se han dejado descubiertas en un ambiente de laboratorio.

Con el fin de asegurar que las caras de la probeta sobre las cuales se aplicará la carga son planas y paralelas entre sí las probetas se han refrentado utilizando una capa fina de escayola (con resistencia superior a la del mortero empleado en la confección de las probetas) (Figura 2).
Specimens were fabricated on a smooth horizontal surface and have taken appropriate measures to prevent desiccation during the first days after construction, after which they were uncovered placed in a laboratory environment.

In order to ensure that the faces of the specimen, on which load will be applied, are flat and parallel to each other, specimens have been facing using a thin layer of plaster (with higher resistance to the mortar used in the preparation of the specimens) (Figure 2).

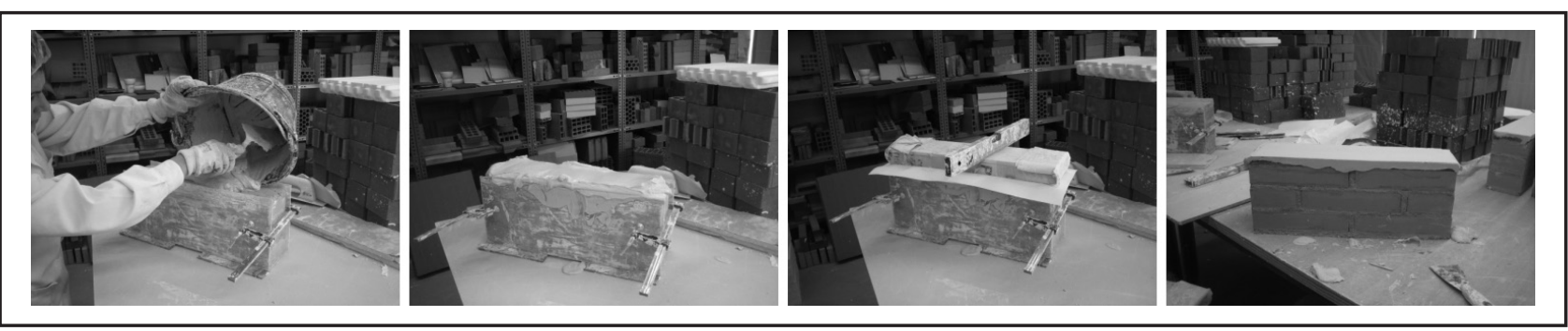

Figura 2. Proceso de refrenado de muretes (vertido y colocación del yeso, compactación y nivelación, estado final). Figure 2. Facing process of wallets (poured and cast placement, compaction and leveling, final state).

\subsection{Sistema de medición y control de la temperatura}

Para calcular el tiempo que el murete tarda en calentarse a determinadas temperaturas se aplica la Ley de Fourier. De esta manera es posible garantizar, para cada escalón de temperatura considerado, que el murete ha alcanzado esa temperatura de forma global.

\subsection{Geometría y disposición del ensayo}

Dado que no existe un ensayo específico para obtener datos sobre la variación del Módulo de Young en elementos de fábrica sometidos a altas temperaturas se diseña un dispositivo para tal efecto.

Según el Eurocódigo (15) para realizar un ensayo a compresión de un elemento de fábrica se necesita una máquina de ensayo que permita aplicar a una probeta una carga tal que los desplazamientos sean uniformes sobre todas las superficies cargadas. Si los platos de la máquina de ensayo son menores que la probeta a ensayar (como era el caso), deben utilizarse vigas de reparto con una longitud mayor que la probeta y un canto mayor o igual a la longitud entre el borde de las placas.

A una máquina de ensayos universal se modifica el puente de ensayos para ajustar las probetas de fábrica con el fin de obtener diagramas tensión deformación a altas temperaturas y para ello se le acopla un dispositivo

\subsection{Measurement system and temperature control}

To calculate the time it takes to heat to certain temperatures the brick wall specimen Fourier's Law is applied. This makes it possible to guarantee, for each temperature step considered, that the wallet has globally reached that temperature.

\subsection{Geometry and layout of the test}

Since there is no specific test to obtain data on the variation of Young's Modulus in masonry wall elements subjected to high temperatures, a device has been designed for this purpose.

According to Eurocode (15) to perform a compression test of a masonry wall element is required a testing machine that can apply to a specimen such a load that the displacements are uniform over all the charged surfaces.If the plates of testing machine were smaller than the specimen to test (as it was), it must be used distribution beams longer than specimens and with thickness equal or bigger than the length between the ends of the plates.

In a universal testing machine the testing bridge is modified to set the wall specimens in order to obtain stress-strain diagrams at high temperatures and for that a heat transfer device is coupled (to ensure 
de transferencia de calor (para conseguir que la acción térmica y la acción mecánica sean concomitantes) (Figuras 3 y 4 ). thermal action and mechanical action are concomitant) (Figures 3 and 4).

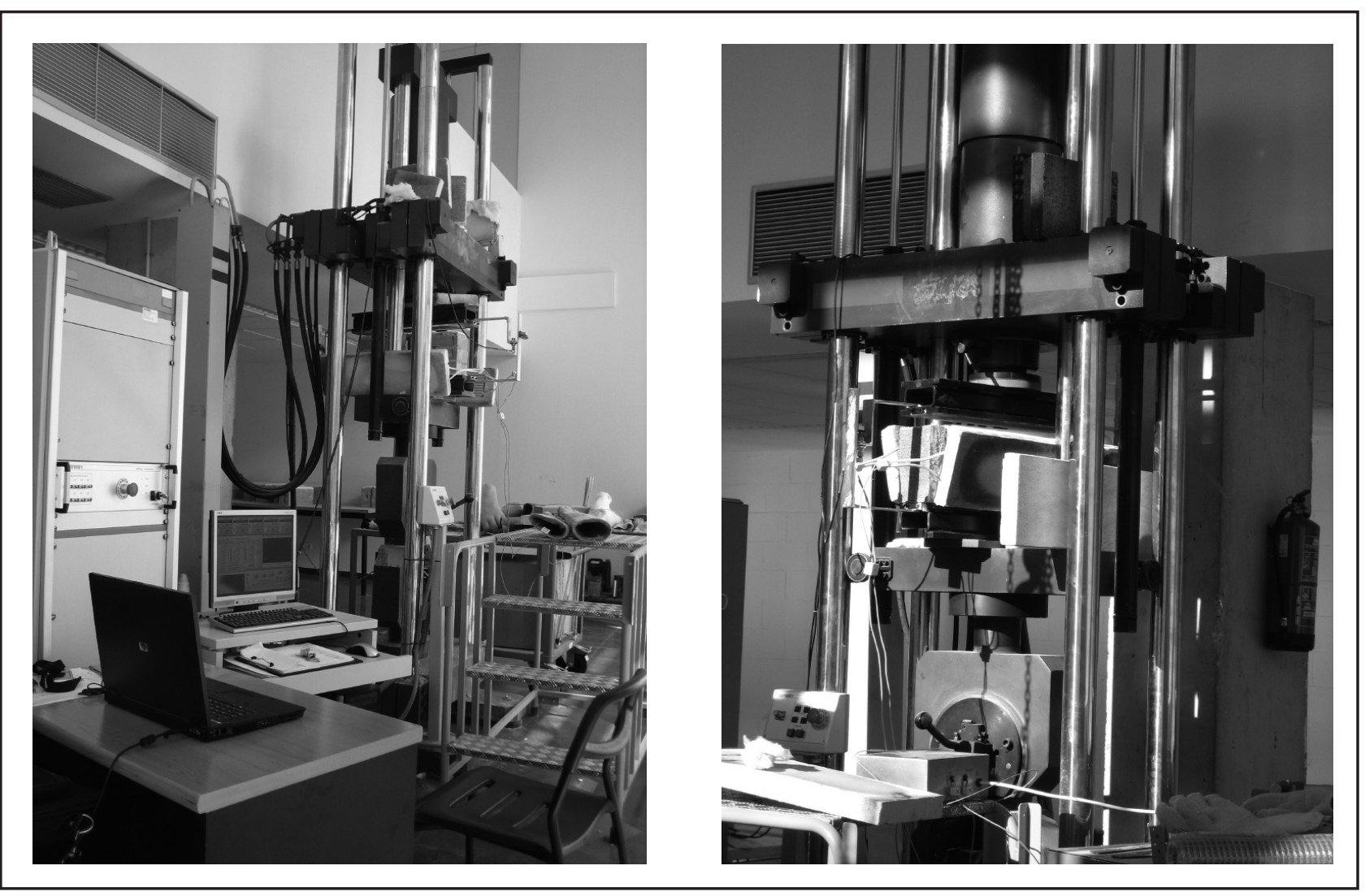

Figura 3. Máquina de ensayos universal. Disposición del ensayo. Figure 3. Universal testing machine. Layout of the test.

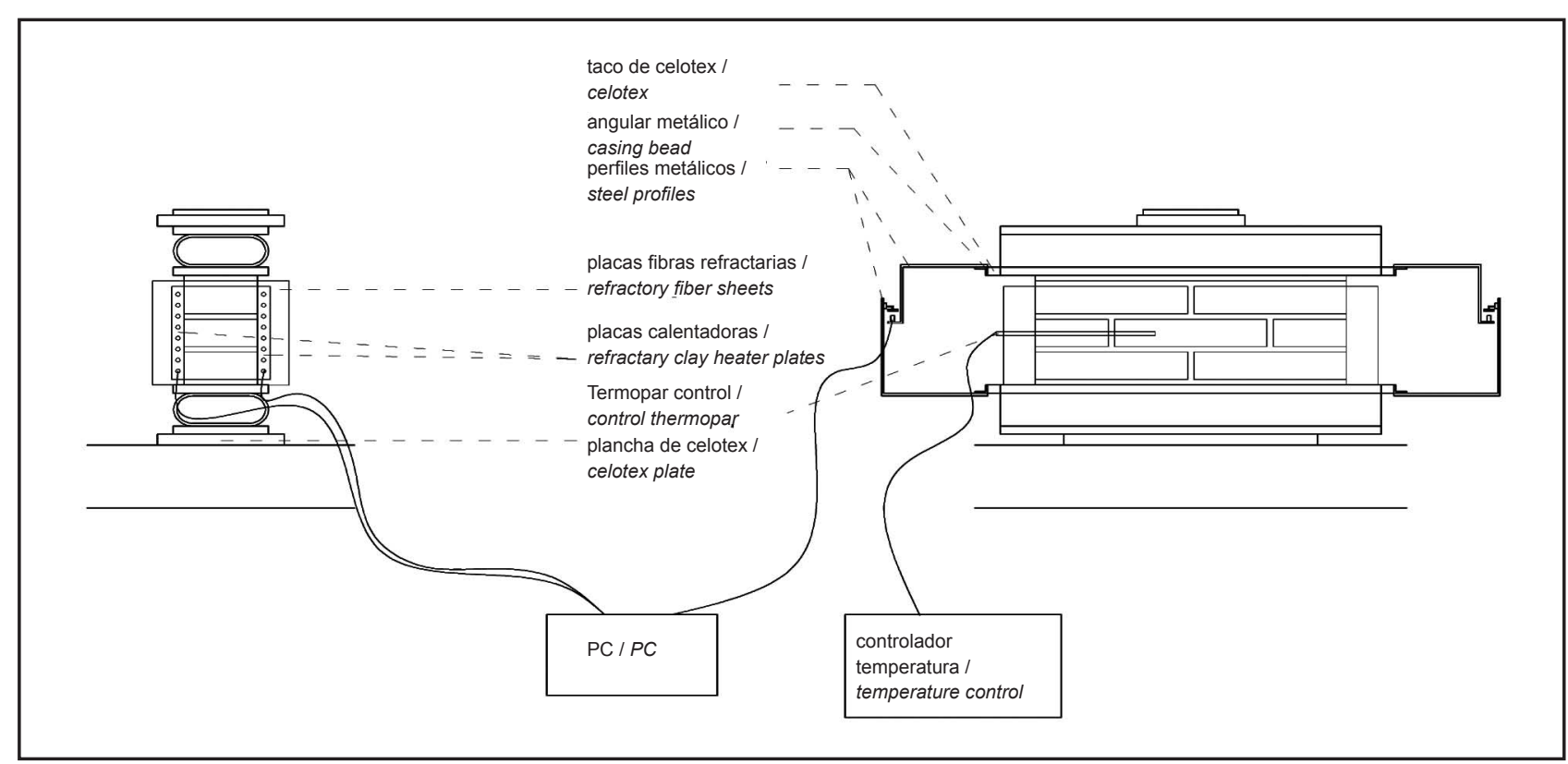

Figura 4. Sistema de medición térmica del murete. Figure 4. Thermal measuring system of the wall. 


\subsection{Sistema de medición del Módulo de Young}

Después de establecer la disposición del ensayo se procede a calentar el murete mediante dos placas calentadoras cerámicas refractarias para conseguir una temperatura homogénea en la probeta con el fin de evaluar la deformación térmica debida a las altas temperaturas. Previo al calentamiento se colocan en los extremos del plano longitudinal del elemento dos medidores magnéticos convenientemente aislados térmicamente (para evitar errores en la medición de los datos).

Durante el ensayo a compresión del elemento de fábrica (acción térmica y mecánica concomitantes) se mide la carga aplicada y las deformaciones del elemento en el sentido vertical de aplicación de la carga gracias a dos medidores magnéticos de deformación colocados, mediante unos perfiles metálicos, en los extremos de las placas de reparto con una precisión de $0,01 \mathrm{~mm}$ y una frecuencia de dos lecturas por segundo.

A través de la relación que se establece entre las tensiones y las deformaciones para cada escalón de temperatura considerado es posible obtener el módulo de elasticidad en cada situación térmica establecida (Tabla 3).

\subsection{Series de ensayo}

Se han estudiado seis series de muretes para cada escalón de temperatura (8 escalones térmicos desde $50{ }^{\circ} \mathrm{C}$ a $\left.700{ }^{\circ} \mathrm{C}\right)$.

Los ensayos se realizaron en el Laboratorio de Estructuras de la Escuela Politécnica Superior de la Universidad San Pablo CEU durante el mes de julio de 2009.

\section{RESULTADOS}

Los resultados relativos a la obtención del módulo de elasticidad del murete a altas temperaturas se dan en la Tabla 2. En ella se define el nombre de la probeta según la nomenclatura establecida, la fecha del ensayo, el rango de temperatura estudiado para cada escalón térmico, la tensión de compresión alcanzada y el valor del módulo de Young alcanzado.

La deformabilidad de las fábricas, representada por el diagrama tensión-deformación, indica el comportamiento de la misma hasta rotura, que se representa mediante el módulo de elasticidad. En el caso del cálculo a temperatura ambiente como módulo de elasticidad secante instantáneo, E, de una fábrica puede tomarse igual a $1.000 \mathrm{fk}(16)$.

\subsection{System of Young's modulus measurement}

After establishing the arrangement of the test we proceeded to heat the wallet by two refractory ceramic heating plates to achieve a uniform temperature in the sample in order to evaluate the thermal deformation due to high temperatures. Previously to heating two magnetic meters suitably insulated (to avoid errors in measurement data) are placed onto the ends of the longitudinal plane of the element.

During compression testing of the masonry element (concomitant thermal and mechanical actions) it is measured the load applied and the deformations of the element in the vertical direction of load application by two strain magnetic meters placed, by means of metal profiles in the ends of the distribution plates with an accuracy of $0.01 \mathrm{~mm}$ and a frequency of two readings per second.

Through the relationship established between the stresses and strains for each temperature step under consideration is possible to obtain the modulus of elasticity in each thermal state set (Table 3).

\subsection{Series test}

We studied six series of wallets for each temperature step (8 thermal steps from $50^{\circ} \mathrm{C}$ to $700^{\circ} \mathrm{C}$ ).

The trials were conducted in the Structures Laboratory of the Polytechnic School of the Universidad San Pablo CEU during the month of July 2009.

\section{RESULTS}

The results for obtaining the modulus of elasticity of the wall at high temperatures are given in Table 2. It defines the name of the specimen using the nomenclature established, the date of trial, the temperature range studied for each thermal step, compressive stress reached and the Young modulus value achieved.

The deformability of the brick wall, represented by the stress-strain diagram indicates its behaviour to break, which is represented by the modulus of elasticity. For the calculation at ambient temperature and elastic modulus instant drying, $E$, of a plant can be taken equal to $1000 \mathrm{fk}$ (16). 
Tabla 2 / Table 2

Datos tensión-deformación-modulo de Young.

Data of stress-strain-Young's modulus.

\begin{tabular}{|c|c|c|c|c|c|c|}
\hline $\begin{array}{l}\text { Nombre de la } \\
\text { probeta / } \\
\text { Name of the } \\
\text { sample }\end{array}$ & $\begin{array}{c}\text { Fecha ensayo / } \\
\text { Test date }\end{array}$ & $\begin{array}{l}\text { Rango } T^{\mathrm{a}} / \\
T^{\mathrm{a}} \text { range }\end{array}$ & $\begin{array}{c}\text { Tensión } \\
\text { Compresión / } \\
\text { Compression } \\
\text { Tension }\left(\mathrm{N} / \mathrm{mm}^{2}\right)\end{array}$ & $\begin{array}{c}\text { Tensión Compresión } \\
\text { Media / } \\
\text { Compression Tension } \\
\text { Media }\left(\mathrm{N} / \mathrm{mm}^{2}\right)\end{array}$ & $\begin{array}{c}\text { Módulo de } \\
\text { Young / } \\
\text { Young Modulus } \\
\left(\mathrm{N} / \mathrm{mm}^{2}\right)\end{array}$ & $\begin{array}{c}\text { Módulo de Young } \\
\text { Medio / } \\
\text { Middle Young } \\
\text { Modulus }\left(\mathrm{N} / \mathrm{mm}^{2}\right)\end{array}$ \\
\hline DC19_140408 & 01/07/2009 & $300^{\circ} \mathrm{C}$ & 5.90 & \multirow{6}{*}{6.89} & 3063.12 & \multirow{6}{*}{3762.11} \\
\hline DC20_140408 & 07/07/2009 & $300^{\circ} \mathrm{C}$ & 6.59 & & 4181.87 & \\
\hline DC21_140408 & $13 / 07 / 2009$ & $300^{\circ} \mathrm{C}$ & 7.07 & & 4540.53 & \\
\hline DC22_210408 & $17 / 07 / 2009$ & $300^{\circ} \mathrm{C}$ & 7.66 & & 3936.82 & \\
\hline DC23_210408 & 28/07/2009 & $300^{\circ} \mathrm{C}$ & 6.29 & & 3038.05 & \\
\hline DC24_210408 & 29/07/2009 & $300^{\circ} \mathrm{C}$ & 7.82 & & 3812.28 & \\
\hline DC25_210408 & $01 / 07 / 2009$ & $400^{\circ} \mathrm{C}$ & 8.03 & \multirow{6}{*}{6.83} & 2423.50 & \multirow{6}{*}{2238.61} \\
\hline DC26_210408 & 07/07/2009 & $400^{\circ} \mathrm{C}$ & 6.67 & & 2576.41 & \\
\hline DC27_210408 & $13 / 07 / 2009$ & $400^{\circ} \mathrm{C}$ & 6.20 & & 1999.28 & \\
\hline DC28_210408 & 17/07/2009 & $400^{\circ} \mathrm{C}$ & 5.98 & & 1408.50 & \\
\hline DC29_210408 & 28/07/2009 & $400^{\circ} \mathrm{C}$ & 7.48 & & 2575.88 & \\
\hline DC30_210408 & 29/07/2009 & $400^{\circ} \mathrm{C}$ & 6.61 & & 2448.12 & \\
\hline DC31_210408 & $02 / 07 / 2009$ & $500^{\circ} \mathrm{C}$ & 7.55 & \multirow{6}{*}{6.57} & 2084.48 & \multirow{6}{*}{1772.72} \\
\hline DC32_210408 & 06/07/2009 & $500^{\circ} \mathrm{C}$ & 6.81 & & 1954.10 & \\
\hline DC33_210408 & 08/07/2009 & $500^{\circ} \mathrm{C}$ & 5.65 & & 1387.96 & \\
\hline DC34_210408 & $14 / 07 / 2009$ & $500^{\circ} \mathrm{C}$ & 5.90 & & 1724.96 & \\
\hline DC35_280408 & $22 / 07 / 2009$ & $500^{\circ} \mathrm{C}$ & 6.36 & & 2004.79 & \\
\hline DC36_280408 & $27 / 07 / 2009$ & $500^{\circ} \mathrm{C}$ & 7.12 & & 1480.04 & \\
\hline DC37_280408 & $03 / 07 / 2009$ & $600^{\circ} \mathrm{C}$ & 6.87 & \multirow{6}{*}{6.51} & 1225.27 & \multirow{6}{*}{1161.83} \\
\hline DC38_280408 & 09/07/2009 & $600^{\circ} \mathrm{C}$ & 5.54 & & 962.44 & \\
\hline DC39_280408 & 15/07/2009 & $600^{\circ} \mathrm{C}$ & 6.12 & & 1092.76 & \\
\hline DC40_280408 & 21/07/2009 & $600^{\circ} \mathrm{C}$ & 5.82 & & 1047.73 & \\
\hline DC41_280408 & 24/07/2009 & $600^{\circ} \mathrm{C}$ & 7.58 & & 1370.75 & \\
\hline DC42_280408 & $31 / 07 / 2009$ & $600^{\circ} \mathrm{C}$ & 7.14 & & 1272.03 & \\
\hline DC43_280408 & 03/07/2009 & $700^{\circ} \mathrm{C}$ & 7.32 & \multirow{6}{*}{6.52} & 836.85 & \multirow{6}{*}{927.51} \\
\hline DC44_280408 & 07/07/2009 & $700^{\circ} \mathrm{C}$ & 7.72 & & 1299.21 & \\
\hline DC45_280408 & $10 / 07 / 2009$ & $700^{\circ} \mathrm{C}$ & 5.80 & & 974.65 & \\
\hline DC46_280408 & 16/07/2009 & $700^{\circ} \mathrm{C}$ & 6.41 & & 756.67 & \\
\hline DC47_280408 & 20/07/2009 & $700^{\circ} \mathrm{C}$ & 5.63 & & 607.20 & \\
\hline DC48_280408 & $30 / 07 / 2009$ & $700^{\circ} \mathrm{C}$ & 6.21 & & 1090.49 & \\
\hline
\end{tabular}

Uno de los parámetros más utilizados, tanto para el ladrillo como para el mortero, es su módulo de deformación ${ }^{1}$. Durante un ensayo de compresión uniaxial se pueden medir las deformaciones producidas conforme se aplica la carga tanto en la dirección de aplicación de la carga como en dirección transversal para obtener el Módulo de Elasticidad.

En este caso las mediciones se realizaron en el plano de aplicación de la carga dando los resultados que aparecen en la Figura 4.

1 A temperatura ambiente es quizá el ensayo más extendido (Ali y Page, 1988; Abboud et al., 1990). Se realiza normalmente con probetas cúbicas de 40 o $50 \mathrm{~mm}$ de arista, obtenidas por moldeo en el caso del mortero, o por corte a partir de un bloque mayor para el ladrillo.
One of the most frequently used parameters, for both the brick and mortar, is their modulus of deformation ${ }^{1}$. Along the uniaxial compression test it is possible to measure deformations produced as the load is putting on in the direction of the load as well as in the transversal direction, in order to obtain the modulus of elasticity.

In this case the measurements were performed at the surface of load application giving the results shown in Figure 4.

1 Ambient temperature test is perhaps the most used (Ali and Page, 1998; Abboud et al., 1990). It is made with $40 \mathrm{~cm} \mathrm{x}$ $40 \mathrm{~mm} \times 40 \mathrm{~mm}$ or $50 \mathrm{~cm} \times 50 \mathrm{~cm} \times 50 \mathrm{~mm}$ cubic specimens, obtained by moulding in the case of mortar or by cutting from a bigger block in the case of brick 
En la Figura 5 se puede apreciar cómo el Módulo de Elasticidad de la fábrica disminuye hasta en un $60 \%$ durante el intervalo de temperaturas desde el ensayo a temperatura ambiente hasta los $400{ }^{\circ} \mathrm{C}$ de temperatura como sucedía en algunos de los resultados sobre ensayos de mortero a altas temperaturas $(3,5)$.
In Figure 5 we can see how the modulus of elasticity of the masonry wall decreases up to $60 \%$ over the temperature range of the assay from ambient temperature to $400{ }^{\circ} \mathrm{C}$ temperature as occurred in some of the results on tests of mortar at high temperatures $(3,5)$.

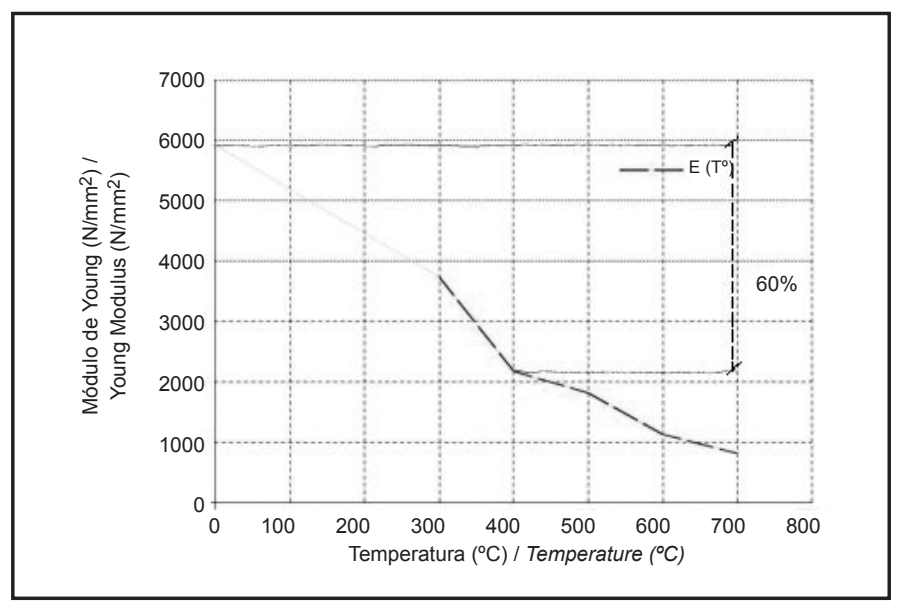

Figura 5. Variación del Módulo de Young del elemento de fábrica en función de la temperatura.

Figure 5. Variation of the Young's modulus of the masonry wall element as a function of temperatura.

De acuerdo con la mayoría de resultados expuestos en el Estado del Conocimiento sobre la evolución del módulo de elasticidad del mortero con respecto de la temperatura se aprecia una brusca caída del mismo entre los escalones térmicos de $200{ }^{\circ} \mathrm{C}$ a $600{ }^{\circ} \mathrm{C}$ (la disminución oscila entre el $20 \%$ y el $70 \%$, respectivamente).

En la Tabla 3 se exponen, según el rango de temperaturas estudiado, la tensión que han resistido las probetas hasta rotura, la deformación media alcanzada y el Módulo de Elasticidad obtenido para esas condiciones. También se refleja la pérdida del Módulo de Elasticidad respecto al inicial (a temperatura ambiente). Cabe señalar, por tanto, que la influencia de la pérdida de resistencia del mortero en los escalones térmicos iniciales unido al deterioro en la adherencia pieza-mortero son los responsables de la
According to most results reported in the State of Knowledge on the evolution of the modulus of elasticity of mortar related to temperature it is seen a sharp drop of it between the thermal steps of $200{ }^{\circ} \mathrm{C}$ to $600{ }^{\circ} \mathrm{C}$ (reduction vary between $20 \%$ and $70 \%$ respectively).

Table 3 shows, according to the temperature range studied, the tension that have withstood the specimens to break, the average strain reached and the modulus of elasticity obtained for these conditions. It also reflects the loss of the elastic modulus compared to the initial (at ambient temperature). It should be noted, therefore, that the influence of mortar strength loss in the initial thermal steps linked to the decline in part-mortar adhesion are responsible for the sharp drop in the rigidity

Tabla 3 / Table 3

Variación del Módulo de Young del elemento de fábrica en función de la temperatura. Variation of Young's modulus of the element factory function of temperature.

\begin{tabular}{|c|c|c|c|c|}
\hline $\begin{array}{c}\text { Rango de temperatura } \\
\text { / Temperature range } \\
\left({ }^{\circ} \mathbf{C}\right)\end{array}$ & $\begin{array}{c}\text { Tensión compresión media / } \\
\text { Compression strength media } \\
\left(\mathbf{N} / \mathbf{m m}^{\mathbf{2}}\right)\end{array}$ & $\begin{array}{c}\text { Deformación longitudinal / } \\
\text { Deformation longitudinal }\end{array}$ & $\begin{array}{c}\text { Módulo de Young / } \\
\text { Young's Modulus } \\
\left(\mathbf{N} / \mathbf{m m}^{\mathbf{2}}\right)\end{array}$ & $\begin{array}{c}\text { Pérdida Módulo de Young / } \\
\text { Young's Modulus Loss (\%) }\end{array}$ \\
\hline 300 & 6.89 & $1.855 \times 10(-3)$ & 3.762 .11 & 36.14 \\
\hline 400 & 6.83 & $3.1425 \times 10(-3)$ & 2.238 .61 & 1.772 .72 \\
\hline 500 & 6.57 & $3.764 \times 10(-3)$ & 1.161 .83 & 70.01 \\
\hline 600 & 6.51 & $5.609 \times 10(-3)$ & 927.51 \\
\hline 700 & 6.51 & $7.347 \times 10(-3)$ & 80.02 & 84.76 \\
\hline
\end{tabular}


brusca bajada de la rigidez de la fábrica (se pierde hasta un $70 \%$ de resistencia de la fábrica a $500{ }^{\circ} \mathrm{C}$ cuando la pieza apenas ha variado su rigidez).

Los valores obtenidos para el módulo de elasticidad a altas temperaturas del elemento de fábrica se han obtenido también gráficamente a través de los diagramas tensión deformación para cada uno de los distintos escalones térmicos estudiados.

\section{DISCUSIÓN}

Aunque existen diversos modelos que caracterizan la dependencia del módulo de Young de los materiales cerámicos cristalinos con la temperatura es posible afirmar, de forma general, que a partir de la temperatura ambiente, el módulo de Young disminuye con la temperatura de forma aproximadamente lineal, siendo la pendiente distinta para cada material.

Puesto que el módulo de elasticidad de los materiales cerámicos no varía con respecto a la temperatura cabe suponer que, gracias a la pérdida de rigidez del mortero (sobre todo a partir de los $300^{\circ} \mathrm{C}$ ), la pérdida de rigidez de la fábrica está directamente relacionada con la disminución de esta propiedad mecánica del mortero.

El estudio de las propiedades térmicas y mecánicas, en el caso particular de los materiales cerámicos, denota una especial complejidad, directamente relacionada con la diversidad estructural que presentan. Por eso, los resultados teóricos o analíticos sobre materiales de naturaleza cristalina únicamente nos serán útiles como guía, siendo en todo caso necesario realizar medidas experimentales y ensayos sobre los materiales cerámicos en cuestión. of the masonry (lose up to $70 \%$ resistance from the masonry at $500{ }^{\circ} \mathrm{C}$ when the piece has hardly changed its stiffness).

Note that the values obtained for the modulus of elasticity at high temperatures of the masonry element have been also obtained graphically through the stress-strain diagrams for each of the different thermal steps studied.

\section{DISCUSSION}

Although there are several models that characterize the dependence of Young's modulus of crystalline ceramics with temperature is usually possible to say that from ambient temperature, Young's modulus decreases with temperature approximately linearly, with different slope for each material.

Since the modulus of elasticity of ceramic materials does not vary with respect to temperature presumably due to the loss of stiffness of the mortar (especially from $300^{\circ} \mathrm{C}$ ), the loss of rigidity of the masonry is directly related to the decline of this mechanical property of mortar.

The study of the thermal and mechanical properties, in the particular case of ceramic materials, denotes a particularly complexity, directly related to the structural diversity in them. Therefore, the theoretical or analytical results on crystalline nature materials will be useful only as a guide; in any case will be necessary experimental measurements and tests on ceramic materials in question.

\section{BIBLIOGRAFÍA / BIBLIOGRAPHY}

(1) Lawrence, S. J.; Gnanakrishnan, N.: "The Fire Resistance of Masonry Walls. An Overview". First National Structural Engineering Conference. Melbourne, pp. 26-28 August (1987).

(2) López, J.; Oller, S.; Oñate, E.: "Cálculo del comportamiento de la mampostería mediante elementos finitos". Monografía CIMNE M46 (1998).

(3) Anderberg, T.; Thelandersson, S.: "Stress and Deformation characteristics of concrete al high temperatures. Experimental investigation and material behaviour model". Institute of Technology, Lund, Sweden. Bulletin 54 (1976).

(4) Gnanakrishnan, N.; Lawther, R.: "Some aspects of the fire performance of single leaf masonry construction". International Symposium on Fire Engineering for Building Structures and Safety. Melbourne. National Conference Publication, vol. 89/16 (1989), pp. 93-99.

(5) Cruz, C. R.: "Elastic Properties of concrete at high temperatures". J. PCA Research and Development Laboratories, vol. 8, no 1 (1966).

(6) Abrams, M. S.: "Behaviour of inorganics materials in fire". Symposium on design of buildings for fire safety. ASTM Special Technical Publications, no 685 (1979).

(7) Lee, J.; Choi, K.; Hong, K.: "Color and material property changes in concrete exposed to high temperatures". Journal of Asian Architecture and Building Engineering, vol 8, n01 (2009), pp. 175-182. http://dx.doi.org/10.3130/jaabe.8.175

(8) Nguyen, T. et al: "The behaviour of masonry walls subjected to fire: Modelling and parametrical studies in the case of hollow burntclay bricks". Fire Safety Journal no 44 (2009), pp. 629-641. http://dx.doi.org/10.1016/j.firesaf.2008.12.006 
(9) Castillo; C.: "Effect of transient high temperatures on high strength concrete". Tesis Doctoral (1987). Rice University. Houston (Texas).

(10) IETcc (CSIC). "Estudio de las propiedades térmicas y mecánicas en elementos de fábrica a través de ensayos en horno". Informe interno. Investigación Prenormativa. Proyecto Código Técnico de la Edificación (2005).

(11) Bazant, Z. P.; Kaplan, M. F.: "Concrete at High Temperatures: Material properties and mathematical models". Concrete design and Construction Series, p. 424, Longman, 1996.

(12) UNE EN 771-1:2003. Especificaciones de piezas para fábrica de albañilería. Parte 1: Piezas de arcilla cocida. AENOR.

(13) UNE EN 998-2:2004. Especificaciones de los morteros para albañilería. Parte 2: Morteros para albañilería. AENOR.

(14) UNE EN 1015-2: 2000. Métodos de ensayo de los morteros para albañilería. Parte 2: Toma de muestra total de morteros y preparación de los morteros de ensayo. AENOR.

(15) UNE EN 1996-1-2:2005. Proyecto de estructuras de fábrica. Parte 1-2: Reglas generales. Proyecto estructural en caso de incendio. AENOR.

(16) CTE DB SE-F, 2006. Documento Básico "Seguridad Estructural para elementos de fábrica". Código Técnico de la Edificación. 